\title{
Sakramentalni pečat i ispovjedna tajna
}

\author{
ZDENKO ILIĆ* \\ UDK: 272-74-543.7 • Pregledni članak \\ Primljeno: 10. siječnja 2017. • Prihvaćeno: 8. svibnja 2017.
}

Sažetak: Kada osoba otvori svoju dušu svećeniku ispovjedni$k u$ da bi ispovjedila svoje grijehe u sakramentalnoj ispovijedi, izmedu njih nastaje sveta veza. Preko svećenika, kao služitelja sakramenta pokore, djeluje Krist koji oprašta grijehe. Svećenik ne može nikome obznaniti rečeno u ispovijedi te je vezan apsolutnom profesionalnom tajnom koju nazivamo sakramentalni pečat. Kann. 983-984 donose dva vida tajnosti koju ispovjednik i drugi koji bi mogli doći do saznanja iz slavlja sakramenta pokore moraju održavati. Ta tajnost odnosi se na sve ono što se čulo u pojedinačnoj ispovijedi. Prema kan. 983 sakramentalni pečat nepovrediv je. Svećenik ispovjednik ne smije obznaniti sadržaj ispovijedi ni izravno ni neizravno preko nekih znakova, sugestija ili činâ. Ako ispovjednik izravno po-

${ }^{*}$ Dr. sc. Zdenko Ilić,

Katolički bogoslovni fakultet u Đakovu

Sveučilišta J. J.

Strossmayera u Osijeku,

P. Preradovića 17,

31400 Đakovo,

Hrvatska, zdenko.ilic@os.t-com.hr vrijedi sakramentalni pečat, odmah upada u kaznu izopćenja (latae sententiae) pridržane Apostolskoj stolici. Ako to učini neizravno, treba biti kažnjen (ferendae sententiae) prema težini kažnjivoga djela (kan. 1388, \$1). Osim ispovjednika, tumač $i$ drugi do kojih je na bilo koji način doprlo znanje o grijesima, obvezni su čuvati ispovjednu tajnu. Ako se toga ne budu držali, mogu biti kažnjeni pravednom kaznom, pa čak i izopćenjem (kan. 1388, \$2).

Kod izravne povrede sakramentalnoga pečata Apostolska pokorničarna mjerodavna je za otpuštanje kazne izopćenja jednim posebnim postupkom. U ostalim slučajevima mjerodavan je ordinarij.

Ključne riječi: sakrament pokore, sakramentalni pečat, ispovjedna tajna, ispovjednik, pokornik, izravna i neizravna povreda, izopćenje, Apostolska pokorničarna. 


\section{Uvod}

U sakramentu pokore ili pomirenja dolazi do izražaja jedan poseban odnos povjerenja. Pokornik otvara svoju savjest svećeniku ispovjedniku upravo jer je ispovjednik. Pokornik mu govori ono što možda nikome ne bi rekao niti to želi reći svećeniku izvan ispovijedi. Sve ono što pokornik kaže ispovjedniku u ispovijedi obično se naziva ispovjedna tajna ili sakramentalni pečat. Crkva je uvijek držala da taj odnos povjerenja zaslužuje posebnu pozornost i zaštitu štiteći ga moralno-pravnim odredbama. Već od postapostolskih vremena, kada su se u Crkvi ustalile pokorničke prakse, potvrdilo se načelo prema kojemu je čin kajanja, odnosno optužba za učinjene vlastite grijehe, u sakramentalnoj ispovijedi bio zaštićen apsolutnom diskrecijom i tajnom koje su dovele do nastanka kanonsko-pravnoga instituta sakramentalnoga pečata i ispovjedne tajne. Da bismo mogli shvatiti današnje moralno-kanonske odredbe o pečatu i tajni, potrebno je osvrnuti se na povijesni, moralni i kanonski iter njihova nastanka, razvoja i primjene u nauku Katoličke Crkve. Zatim će uslijediti analiza važeće discipline i zaštite pečata i tajne u kontekstu kanonskoga zakonodavstva Crkve zapadnoga ili latinskoga obreda.

\section{Kratak povijesno-pravni osvrt ${ }^{1}$}

Već od prvih stoljeća Crkve obveza čuvanja sakramentalnoga pečata i ispovjedne tajne usko je povezana s povijesnim razvojem oblika slavlja sakramenta pokore. $U$ kontekstu kanonske pokore ta obveza čuvanja bila je njezin bitan element. Osim velikih grijeha, koji su po svojoj naravi pripadali javnom području i svima bili poznati (ubojstvo, preljub i otpad od vjere), za ostale se grijehe pokornik, kako bi ušao u red pokornika, morao optužiti pred biskupom ili svećenikom kojega bi biskup ovlastio. Nakon toga uslijedila bi pokora koja je bila javnoga karaktera, a ne ispovjeđeni grijesi.

Međutim, u praksi su ispovjednici vrlo često zloupotrjebljavali sadržaj ispovijedi na izvanjskom području, na što su upozoravali mnogi crkveni sabori, crkveni oci, teolozi, moralisti i kanonisti. Posljedično tomu polako se razvijala moralno-kanonska obveza strogoga čuvanja ispovjedne tajne, a kasnije i sakramentalnoga pečata.

Kao konkretne primjere toga mukotrpnoga razvoja kronološkim redom donosimo najvažnije njihove istupe:

\footnotetext{
${ }^{1}$ Povijesno-pravnu analizu razvoja instituta sakramentalnoga pečata temeljimo na vrlo poznatome djelu talijanskoga kanonista Cappello. Usp. F. M. CAPPELLO, De sacramentis, u: Tractatus canonico-moralis, vol. II, Roma, 1929., br. 723-784.
} 
Komentirajući Levitski zakonik, Origen (185-284.) u svojoj propovijedi poziva pokornike da ne zatajuju osobne grijehe, koje treba reći u ispovijedi i koji ostaju tajna, nego da javne postaju samo okajničke kazne. ${ }^{2}$

Afrate Sirijac napisao je Sirijski biblijski komentar (336. - 345.). U njemu su sadržane njegove propovijedi u kojima, među ostalim, naređuje ispovjednicima da ne obznanjuju grijehe koje su im pokornici očitovali u ispovijedi riječima nolite eam publicare. ${ }^{3}$

Prvi siguran dokument o tajnosti optužbe za grijehe nalazimo kod pape Leona Velikoga (459.) koji istupa u slučaju biskupa talijanske regije Campania s obzirom na to da su oni tražili od vjernika da grijesi, napisani na papiru, budu javno izrečeni. ${ }^{4}$

Koncil u Armeniji (527.), poznat pod imenom Concilium Tovoniense, proglasio je različite disciplinske kanone kako bi se stalo na kraj nedostojnom ponašanju pojedinih svećenika. Među njima nalazi se i prvi kanon protiv jednoga svećenika okrivljenoga za povredu sakramentalne tajne: can. 20: »le prête qui trahirait le secret de la confession serait frappé d'anathème. $\ll^{5}$

Nažalost, od petoga pa sve do desetoga stoljeća imamo sve više istupa raznih crkvenih učitelja zbog sve češćega obznanjivanja grijeha iz ispovijedi. Npr. Pavao, patrijarh Akvileje, opominje svećenike da trebaju otrti i ozdraviti rane svojih pokornika bez da im javno obznanjuju njihove grijehe. Na istoj su liniji Hincmar, nadbiskup Reimsa, te papa Grgur Veliki. ${ }^{6}$ Osim njih, napose je zanimljiv istup blaženoga Lanfranka Kenterberijskog (1005. - 1089.) prema kojemu obveza čuvanja tajne ne pripada samo službeniku sakramenta pokore nego i pokorniku. ${ }^{7}$

Anzelmo iz Lucce (1035. - 1086.) u svom djelu Collectione canonum uvrstio je jedan kanon na koji su se od tada pozivali mnogi autori 11. stoljeća. U tom kanonu

${ }^{2}$ ORIGENES, u: Patrologia Graeca, Migne, Paris, 1862, to. XII, par. 207-208, 451.-452.

${ }^{3}$ AFRATE, u: Patrologia Syriaca, p. I, to. I, a cura di R. GRAFFIN, Instituti Francici Typographi, Parisiis, 1894., 318.-319.

${ }^{4}$ Usp. LEON VELIKI, Pismo $\gg$ Magna indignatione « svim biskupima u Kampaniji itd., 6. ožujka 459., u: H. DENZINGER-P. HÜNERMANN, Zbirka sažetaka, vjerovanja, definicija i izjava o vjeri i ćudoređu, Đakovo, 2002., br. 323 (= DH).

${ }^{5}$ H. LECLERCQ Histoire des Conciles d'après les documents originaux, Paris, 1908, to. II, p. II, 1079.

${ }^{6}$ Usp. SANCTUS PAULINUS, Patriarcha Aquileiensis, u: Patrologia latina, Migne, 1851., sv. XCIX., 257.-258.; HINCMARUS, Rhemensis archiepiscopus, u: Patrologia latina, Migne, 1852., sv. CXXV., 634.; GREGORIUS MAGNUS, u: Patrologia latina, Migne, 1849., sv. LXXVII., 33.

${ }^{7}$ Usp. BEATUS LANFRANCUS, Cantuariensis archiepiscopus et AngliAe primas, u: Patrologia latina, Migne, 1854., sv. CL, 627. 
poziva svakoga svećenika da se prije svega čuva da ispovjeđene grijehe nikomu ne govori. Ako to učini, neka sramotan hodi cijeli svoj život. ${ }^{8}$

U narednim stoljećima, sve do skolastičkoga doba, pojavljuje se tarifna pokora pod utjecajem irskih monaha. Sada se pokora obavlja odmah nakon ispovijedi i to privatno, a ne više javno, pa čak je bilo moguće da se pokora zajednički obavi.

U Gracijanovu Dekretu iz 1151. godine, u kojem je sadržan nauk koncilâ i papinskih odluka Crkve prvoga tisućljeća, s obzirom na sakramentalni pečat nalazimo sljedeću izjavu: »Deponatur sacerdos qui peccata poenitentis publicare praesumit $\ll^{9}$, tj. svećenik koji se usudi obznaniti grijehe pokornika neka bude skinut/uklonjen. Prekršitelj te odredbe neka bude kažnjen kao sramotni lutalica.

Pariška sinoda (1203. - 1214.) u konst. 38 donijela je sljedeću odluku: »Nullus ira vel odio vel etiam metu mortis, in aliquo audeat revelare confessionam signo vel verbo, generaliter vel specialiter; ut dicendo 'Ego scio quales estis'; et, si revelaverit, absque misericordia debet degradari. ${ }^{10}$

Četvrti lateranski koncil (1215.) donio je jednu od prvih nauka s obzirom na sakrament pokore. Suočivši se s različitim problemima, od zloupotreba do heretičkih stavova o ispovijedi, koncil je definirao sam sakrament, donio odluku o godišnjoj ispovijedi i pričesti te donio disciplinske mjere za svećenike ispovjednike koji ih se ne budu držali. Tako npr. kan. 21 toga koncila određuje zakon o čuvanju sakramentalnoga pečata za cijelu Crkvu. Prema tom kanonu svećeniku je zabranjeno izdati pokornika bilo riječima bilo znakovima ili na bilo koji drugi način pod kaznom oduzimanja svećeničke službe, ali i životnom pokorom pod strogim nadzorom u nekom samostanu. ${ }^{11}$

Toma Akvinski (1225. - 1274.), među ostalim, poznat je i po tome što nam je u pet članaka ostavio traktat o sakramentalnom pečatu. U prvom članku izlaže nauk o apsolutnoj obvezi tajnosti ispovijedi; u drugom obrađuje temu obznanjivanja onoga što ne pripada materiji sakramentalne ispovijedi; u trećem govori o obvezi tumača

\footnotetext{
$8 \gg$ Caveat ante omnia sacerdos, ne de his qui peccata sua confitentur, alieni recitet quod ea confessus est, non propinquis, non extraneis, [...] pro aliquo scandalo. Nam, si hoc fecerit, deponatur et omnibus diebus vitae suae ignominiosus peregrinando pergat.«, u: Decretum Gratiani, IV, c. 2, D. VI, «De poenitentia «.

${ }^{9}$ Decretum Gratiani, secunda pars, dist. VI, c. I.I.

${ }^{10}$ ODO DE SOLIACO, Parisiensis episcopus, Synodicae constitutiones, u: Mansi, Concil., XXII, 62.

11 »[Sacerdos] caveat omnino ne verbo aut signo aut alio quovis modo aliquatenus prodat peccatorem: sed in prudentiore consilio indiguerit, illud absque ulla expressione personae caute requirat, quoniam qui peccatum in peanitentiali iudicio sibi detectum presumpserit revelare, non solum a sacerdotali officio deponendum decernimus, verum etiam ad agendam perpetuam paenitentiam in arctum monasterium detrudendum.«, u: DH 813.
} 
na tajnost ispovijedi; u četvrtom o mogućnosti pokornika da ovlasti ispovjednika na otkrivanje materije ispovijedi te u petom članku raspravlja smije li se i na koji način ispovjednik služiti saznanjima iz ispovijedi. ${ }^{12}$

Na ekumenskom koncilu u Firenci (1439.) objavljen je 28. lipnja Dekret jedinstva s Grcima, a 22. studenoga Dekret jedinstva s Armencima. Na temelju tih dekreta odredilo se sljedeće: ispovijed je individualna i privatna; cjelovito učinjena pred službenikom, a njezin su objekt svi smrtni grijesi. ${ }^{13}$

Tridentski sabor na svom zasjedanju 15. listopada 1551. godine raspravljao je o sakramentu pokore. Osnovavši dvije komisije da priprave sav materijal u vezi s tim sakramentom te nakon mnogih rasprava tijekom studenoga iste godine, 25. studenoga proglašena su dva kanona kojima se točno utvrđuje materija ispovijedi, način ispovijedanja te obveza tajnosti. ${ }^{14}$

Nakon Tridentskoga sabora nije bilo nekih većih novina s obzirom na kanonsku disciplinu sakramenta pokore i sakramentalnoga pečata. Tom su se tematikom više bavili sami moralisti s pomoću tzv. kazuistike.

Kada je riječ o kanonskim odredbama nakon Tridentskoga sabora, evo nekih značajnijih:

Papa Klement VIII. izdao je 26. svibnja 1593. godine dekret Sanctissimus Dominus noster kojim poziva sve redovničke poglavare da se najbrižljivije čuvaju (caveant diligentissime) korištenja saznanja o grijesima iz ispovijedi nad svojim podanicima. ${ }^{15}$

Kongregacija de Propaganda fidei izjasnila se 6. rujna 1630. godine o sudjelovanju tumača pri sakramentu pokore. Ona poziva patrijarhatskoga vikara Konstantinopola da ne brani ispovijedi s pomoću tumača. On pak mora biti svjestan težine svoje uloge pri ispovijedi te ga obvezuje tajnost svega onoga što bude čuo i prevodio svećeniku ispovjedniku.

Generalni vikar talijanske biskupije Trento zatražio je od redovnika jedne određene zone te biskupije da mu općenito kažu koji su to grijesi graviora koje vjernici ispovijedaju. Naravno, redovnici su odbili odgovoriti na taj upit zbog sakramentalnoga pečata i da bi zaštitili same pokornike. Stoga je isti generalni vikar uputio zahtjev Svetoj Kongregaciji Koncila u kojem od nje traži dozvolu za svoj naum.

\footnotetext{
${ }^{12}$ Usp. T. D’AQUINO, De Poenitentiae, u: Summa Theologiae, suppl. q. 11, sv. XXIX, Salani, Roma, 1971., 335.

${ }^{13}$ Usp. DH 1323.

${ }^{14}$ Usp. kan. 6, u: DH 1706 i kan. 8, u: DH 1683.

${ }^{15}$ Usp. DH 1989.
} 
Međutim, Kongregacija mu je 19. kolovoza 1673. godine dala negativan odgovor. ${ }^{16}$ Nekoliko godina kasnije Kongregacija sv. Oficija objavila je (18. studenoga 1682. godine) dekret kojim se apsolutno zabranjuje korištenje saznanjima iz ispovijedi.

U međuvremenu se pojavila praksa da su pokornici nakon ispovijedi i odrješenja dobivali potvrdu kojom su mogli pristupiti svetoj pričesti. O tome se izjasnila Kongregacija de Propaganda fidei 14. siječnja 1806. godine koja je, zbog takve prakse, upozorila na opasnost povrede sakramentalnoga pečata. Ista Kongregacija godinu dana kasnije, 13. travnja 1807. godine, donijela je odluku kojom se zabranjuje slavlje sakramenta pokore u privatnim kućama, osim u iznimnim slučajevima. Osim toga, svećenici moraju biti prikladno pripremljeni za slavlje toga sakramenta te, poštujući tajnost ispovijedi, odriješiti samo one pokornike koji se iskreno kaju zbog počinjenih grijeha. ${ }^{17}$

\section{Kanonske odredbe o sakramentalnom pečatu i ispovjednoj tajni ${ }^{18}$}

Budući da kan. 983 važećega Zakonika skoro doslovno preuzima odredbu Kodeksa ${ }^{19}$ iz 1917. godine, korisno je osvrnuti se na komentare kanona Kodeksa, napose one koje je u svom traktatu napisao prof. Cappello. ${ }^{20}$

Kann. 889-890 Kodeksa iz 1917. godine donose nam temeljne odredbe o sakramentalnom pečatu, ispovjednoj tajni i zabrani korištenja znanjem iz ispovijedi.

Kan. 889, \$1: »Pečat je ispovjedne tajne nepovredljiv; zato mora ispovjednik brižljivo paziti, da ni riječju ni znakom ni bilo kojim načinom ni bilo $s$ kojeg razloga kakogod ne oda grješnika; $\$ 2$. Dužnost čuvati ispovjednu tajnu obavezuje i tumače i sve druge osobe, koje su bilo kojim načinom saznale za sadržaj ispovijedi.«

${ }^{16}$ Usp. SACRA CONGREGATIO CONSISTORIALIS, Iuris canonici fontes, sv. V, Typis poliglottis Vaticanis, 1930., 231.-235.

${ }^{17}$ Usp. SACRA CONGREGATIO DE PROPAGANDA FIDE, Iuris canonici fontes, sv. VII, Typis poliglottis Vaticanis, 1935., 214.

${ }^{18}$ Rječnik hrvatskoga jezika ovako definira oba pojma: pečat: 1. predmet u urezanim reljefnim znakom koji se može otisnuti na čemu; 2. otisak s pomoću takve naprave kao dokaz ispravnosti čega; tajna: 1 . ono što se nikome ne smije reći, ono što mora ostati skriveno, ono što se taji, skriva, što se ne priča, ne objavljuje; 2 . ono što je nepoznato, neotkriveno, nedostupno spoznaji. U: V. ANIĆ, Rječnik hrvatskog jezika (III. izdanje), Zagreb 1998.

${ }^{19}$ Kodeks kanonskog prava s izvorima 1917., uređen po odredbi sv. oca pape Pija X., proglašen po nalogu pape Benedikta XV. S predgovorom, izvorima i stvarnim kazalom stožernika Petra Gasparrija, Zagreb, 2007.

${ }^{20}$ Usp. F. M. CAPPELLO, De Poenitentia, u: Tractatus canonico-moralis de Sacramentis, sv. II., Torino 1943., br. 614-621. 
Presudan je početak: $\gg \$ 1$. Pečat je ispovjedne tajne nepovredljiv.« Kao što vidimo, tehnički kanonski izraz jest pečat (sigillum) kojim se štiti sadržaj ispovijedi od bilo kakvoga pokušaja njegova odavanja. Stoga ispovjednik mora »brižljivo paziti « da ga ne povrijedi. Drugi paragraf u svom latinskom izvorniku također se koristi izrazom pečat, a odnosi se na tumače i druge. Međutim, zbog terminološke jasnoće hrvatski prijevod Kodeksa upotrebljava riječ tajna. Razlog tomu jest da obveza čuvanja pečata, odnosno tajne, sa sobom nosi ne samo različite subjekte koji su njima vezani nego i u slučaju njihove povrede različite kanonsko-kaznene posljedice.

Iako nema opasnosti od objavljivanja sadržaja ispovijedi ili od moguće štete za pokornika, nikada nije dopušteno služiti se stečenim saznanjima iz ispovijedi ako bi ona mogla dovesti do sablazni ili uvrede vjernika ili sumnje da je povrijeđen sakramentalni pečat. O tome nam govori kan. 890 u svojim dvama paragrafima: $\$ 1$. »Iako ne postoji nikakva pogibao, da se sazna, što je bilo predmetom ispovijedi, ipak je ispovjedniku bezuvjetno zabranjeno, da se posluži onim, što je saznao u ispovijedi, kada bi to za pokornika moglo biti neprilično. $\$ 2 S$ onim, što saznaju o grijesima u ispovijedi, ne smiju se u izvanjem upravljanju poslužiti tadanji Poglavari ni ispovjednici, koji Poglavarima postanu kasnije.«

Ta kanonska odredba proizlazi iz nauka Kongregacije sv. Oficija koja je 18. studenoga 1682. godine donijela dokument kojim se zabranjuje korištenje informacijama iz ispovijedi ako se pojavi opasnost njezina obznanjivanja ili ako bi to bilo na štetu pokornika ili bi se zbog toga stvorio odbojan stav prema ispovijedi.

U tom kontekstu potrebno je nadovezati se i na instrukciju sv. Oficija od 9. lipnja 1915. godine koja govori o nepovredivosti sakramentalnoga pečata. ${ }^{21}$ Iako ta instrukcija ima samo svoju povijesnu vrijednost, ona ipak donosi trajno valjana i obvezujuća načela. Naime, ona poziva ispovjednike da se pri propovijedanju ili raznim duhovnim obnovama suzdrže korištenja raznim primjerima koje su čuli u sakramentu pokore. Isto tako upozorava ih da se ne koriste činjenicama, okolnostima ili situacijama koje bi mogle upućivati na neki određeni grijeh.

Može se postaviti pitanje ima li iznimaka s obzirom na zabranu korištenja znanjem iz ispovijedi, odnosno je li ta zabrana apsolutnoga karaktera. Korištenje saznanjima iz ispovijedi nikada nije dopušteno zbog opasnosti objavljivanja objekta ispovijedi ili nastanka moguće štete za pokornika ili zbog opasnosti od sablazni vjernika. Pred teškim i perpleksnim slučajevima ispovjedniku je dopušteno konzultirati se s nekim tko je kompetentan u određenoj materiji. Naravno, njegov upit mora biti tako

${ }^{21}$ Čudno je da spomenuta instrukcija nikada nije bila objavljena niti u Acta Apostolicae Sedis niti ju nalazimo u DH. U cijelosti je donosi prof. Cappello u spomenutom kanonsko-moralnom traktatu: Usp. F.M. CAPPELLO, De Sacramentis, sv. II, dio I, br. 721. 
formuliran da se ni na koji način ne može saznati ime pokornika. Ako je to nemoguće, tada je za njega bolje da sâm riješi slučaj uzdajući se u Boga. ${ }^{22}$

Zakonik kanonskoga prava iz 1983. godine u kan. 983 ovako govori o ispovjednom pečatu: $\gg \$ 1$. Sakramentalni je pečat nepovrediv; stoga ispovjednik ne smije ni riječima ni na bilo koji drugi način ni zbog bilo kojeg razloga nikako odati pokornika. $\$ 2$. Obvezni su čuvati tajnu i tumač, ako ga ima, i svi drugi do kojih je na bilo koji način iz ispovijedi doprlo znanje o grijesima.«

Originalni latinski izraz sigillum sacramentale Zakonik prevodi riječima sakramentalni pečat, a izraz confessionis secretum riječima ispovjedna tajna. Iako se u svakodnevnom govoru ti pojmovi gotovo izjednačuju u njihovoj primjeni i tumačenju, ipak njihov sadržaj, tumačenje i primjena nisu istoznačni. Stoga ćemo se u daljnjem promišljanju držati te terminološke razlike.

Osim Zakonika, o tome govori i Katekizam Katoličke crkve $e^{23}$ (dalje KKC). Nažalost, izvorni latinski tekst Katekizma Katoličke crkve te njegov hrvatski prijevod iz 1994. godine nisu dosljedni u terminologiji. U prvom dijelu br. 2490 latinski tekst koristi se riječju secretum, a hrvatski je prevodi 'tajna'. U drugom dijelu, citirajući kan. 983 $\$ 1$, latinski izvornik koristi se riječju sigillum, a hrvatski tekst ne drži se kanonskoga prijevoda 'pečat', nego ostaje pri istom pojmu tajna. Evo cijeloga teksta: $\gg$ Tajna sakramenta pomirenja jest sveta, i ne može biti izdana ni pod kojom izlikom. 'Sakramentalna je tajna nepovrediva; stoga je ispovjedniku apsolutno zabranjeno izdati pokornika bilo u čemu, riječima ili na drugi način, i iz bilo kojega razloga. «

\section{Značenje izraza sakramentalni pečat $i$ ispovjedna tajna}

\subsection{SAKRAMENTALNI PEČAT}

Prema već spomenutom prof. Cappello, sakramentalni pečat može se promatrati u dvostrukom smislu, užem i širem. U užem je smislu sakramentalni pečat vrlo uska obveza (obligatio strictissima) čuvanja tajne i uzdržavanja od bilo kojega izvansakramentalnoga korištenja bez pristanka pokornika svega onoga što je pokornik rekao s nakanom da dobije sakramentalno odrješenje, a čije bi otkrivanje ili korištenje izdalo pokornika ili bi najmanje dovelo do sumnje kod onih koji slušaju ili vide. U širem je smislu vrlo uska obveza čuvanja tajne i uzdržavanja od bilo kojega izvansakramentalnoga korištenja bez pristanka pokornika svega onoga što je pokornik rekao s nakanom da dobije sakramentalno odrješenje, a čije bi otkrivanje ili korište-

\footnotetext{
${ }^{22}$ Usp. M. RIVELLA, Il confesore educatore: l'uso delle conoscenze acquisite dalla confessione, u: Quaderni di diritto ecclesiale 8(1995.)4, 415-416.

${ }^{23}$ Katekizam Katoličke crkve, Zagreb, 1994.
} 
nje učinilo sakrament ispovijedi teškim i omraženim..${ }^{24}$ Prema tomu, u užem smislu objavljivanje sadržaja ispovijedi, bilo izravno bilo neizravno, dovodi do povrede tajne pečata. U širem smislu riječ je o korištenju znanjem iz ispovijedi na štetu pokornika što pak dovodi do povrede ispovjedne tajne. »Ta tajna, koja ne dopušta iznimke, naziva se sakramentalni pečat, jer ono što je pokornik rekao ispovjedniku ostaje zapečaćeno sakramentom.«(KKC 1467)

Kada je riječ o pokorniku, postavlja se pitanje obvezuje li i njega sakramentalni pečat. Iako neki autori smatraju da pokornik može ispovjednika osloboditi obveze čuvanja sakramentalnoga pečata, ipak, to nije moguće jer sakramentalni pečat štiti i sam sakrament pokore zbog čega odluka o oslobođenju obveze čuvanja pečata nije u rukama pokornika.

\subsection{ISPOVJEDNA TAJNA}

Izrazom tajna zakonodavac je htio utvrditi obvezu svih subjekata koji su različiti od ispovjednika. Odredbu nalazimo u spomenutom kan. 983, \$2: >obvezni su čuvati tajnu tumač, ako ga ima, kao i svi drugi do kojih je na bilo koji način iz ispovijedi doprlo znanje o grijesima.«

Pravna odredba $\gg$ tumač $[\ldots]$ kao i svi drugi «, odnosno svi oni koji su zakonito, slučajno ili nezakonito došli do saznanja sadržaja ispovijedi. Na primjer, ako netko prolazi uz ispovjedaonicu s nakanom da čuje ono što pokornik ili ispovjednik govori, bila bi riječ o nezakonitom saznanju sadržaja ispovijedi. Ako je riječ o tumaču koji je s pokornikom nazočan u ispovjedaonici, bilo zbog nepoznavanja jezika bilo zbog gluhonijemih osoba, tada bi bila riječ o zakonitoj nazočnosti. O tome nam govori kan. 990: »Nikome nije zabranjeno ispovijedati se preko tumača, kloneći se, dakako, zloporaba i sablazni i uz obdržavanje propisa kan. 983 , $\$ 2 . \ll$ Dakle, oni su vezani ispovjednom tajnom, a ne sakramentalnim pečatom.

\section{Karakteristike sakramentalnoga pečata i ispovjedne tajne $e^{25}$}

Kanonski zakon o sakramentalnom pečatu odnosi se samo na ispovjednika. Svi ostali koji zbog bilo kojega razloga dođu do saznanja sadržaja ispovijedi, npr. tumač ili drugi koji su slučajno čuli sadržaj ispovijedi, nisu vezani sakramentalnim pečatom, nego ispovjednom tajnom.

\subsection{NaStanak}

Prema redovitom obliku slavlja sakramenta pokore sakramentalni pečat nastaje kada pokornik očituje svoje grijehe svećeniku ispovjedniku s nakanom da od nje-

\footnotetext{
${ }^{24}$ Usp. F. M. CAPPELLO, De Sacramentis, br. 723.

${ }^{25}$ Usp. J. BRKAN, Pravna zaštita sakramenta pokore, u: Bogoslovska smotra 75(2005.)1, 397.-402.
} 
ga, kajući se zbog učinjenoga, dobije odrješenje i pokoru. Stoga od trenutka kada pokornik započinje: »Blagoslovi me, oče, jer sam sagriješio «, pa sve do posljednjih riječi odrješenja informacije koje su razmijenjene između ispovjednika i pokornika zaštićene su sakramentalnim pečatom. Čak i onda ako je ispovijed učinjena u manje formalnom obliku, a ispovjednik je udijelio odrješenje, i takav slučaj ulazi u sakramentalni pečat. Posljedično tomu ispovjednik je vezan sakramentalnim pečatom prema svima, uključujući i pokornika.

Međutim, postoje neke okolnosti koje ne dovode do nastanka sakramentalnoga pečata. Evo nekih: nema sakramentalnoga pečata ako se pokornik ne kaje zbog učinjenih grijeha zbog čega dolazi do uskrate odrješenja; ako se pokornik koristi ispovijedi za osobni odušak od određenih životnih poteškoća; ako traži neku vrstu duhovnoga razgovora; ako od toga susreta očekuje nešto drugo, a ne odrješenje grijeha (npr. milostinju ili neku uslugu). U tim i sličnim slučajevima ne nastaje sakramentalni pečat, nego za svećenika nastaje obveza ispovjedne tajne ex iustitia et ex caritate jer pokornik ima pravo na dobar glas i da ne bi nastao skandal (usp. kan. 220).

\section{2. ОвЈект}

Ono što se odnosi na objekt sakramentalnoga pečata i što ispovjednik nikada ne smije odati jesu svi i pojedinačni teški grijesi i laki, ali samo ako su pojedinačno ispovjeđeni ili pripadaju samo jednoj vrsti grijeha. Obznaniti da je neka osoba učinila lake grijehe nije povreda pečata, nego ispovjedne tajne. Zatim eventualna pojašnjenja kao što su situacije u kojima se dogodio neki grijeh, mjesto i vrijeme, osobe koje su možda u tome sudjelovale, svrha ili nakana zbog koje je grijeh učinjen. U objekt ulazi i nametnuta pokora ako bi mogla dovesti do mogućnosti saznanja nekoga grijeha. Na kraju, uskraćeno ili dano odrješenje pokorniku.

\subsection{Obveza ČuvanJa}

Obveza čuvanja sakramentalnoga pečata obveza je božanskoga prava, a obveza čuvanja ispovjedne tajne pozitivnoga crkvenoga prava. Obveza sakramentalnoga pečata proizlazi jedino iz sakramentalne ispovijedi učinjene s nakanom zadobivanja odrješenja pa makar ono bilo uskraćeno. Traži se, i to je dovoljno, da se pokornik optužio za učinjene grijehe. Od toga trenutka ispovjednik je vezan sakramentalnim pečatom. To znači da je ispovjednik vezan posebnim pravnim i moralnim odnosom s pokornikom zbog čega se ne dopušta nikakva iznimka. Ni jednom ispovjedniku ne se može dati oprost obveze čuvanja sakramentalnoga pečata, makar ga to dovelo i u situaciju opasnu po njegov život.

Bez sumnje, ispovjednik mora biti svjestan rečenoga u ispovijedi te se mora čuvati svake opasnosti povrede sakramentalnoga pečata, čime bi doveo u opasnost i po- 
vjerenje pokornika i sam sakrament pokore. Ako bi ispovjednik htio razgovarati s pokornikom o ispovjeđenim grijesima nakon ispovijedi, za to bi trebao njegovo dopuštenje. Osim ako se to dogodi odmah nakon ispovijedi, tada bi se takav čin smatrao moralnim nastavkom ispovijedi, ili ako u narednim susretima sam pokornik ne otvori razgovor o rečenom u prijašnjoj ispovijedi. Ni smrt pokornika ne može osloboditi ispovjednika sakramentalnoga pečata.

Nadalje, ispovjednik ne smije povrijediti sakramentalni pečat ni onda kada bi time mogao spasiti svoj život ili sačuvati svoj dobar glas, ili da bi upozorio na lažnu optužbu, ili da bi spasio drugomu život, ili da bi pomogao u kaznenom postupku otkrivši počinitelja. Ni jedan civilni zakon ne može ga pravno obvezati da povrijedi sakramentalni pečat niti ga se može pozvati kao svjedoka na suđenju. ${ }^{26}$ Naime, kan. $1550, \$ 2$ o2 određuje da su kao svjedoci nesposobni $\gg$ svećenici, s obzirom na sve što im je poznato iz sakramentalne ispovijedi, iako pokornik traži da se to očituje; dapače, što se čulo od bilo koga i bilo kako prigodom ispovijedi ne može se prihvatiti ni kao pokazatelj istine «. Taj kanon povezan je s kan. 1388, \$2 koji određuje da budu kažnjeni pravednom kaznom tumač i ostali koji su došli do saznanja sadržaja ispovijedi, a ne drže se ispovjedne tajne. Inače, nikakva kazna nije predviđena za ispovjednika koji se neoprezno služi informacijama stečenim u sakramentalnoj ispovijedi. Razlog tomu je da je skoro nemoguće sa sigurnošću utvrditi i odrediti povredu takvoga tipa tajne.

\subsection{Posebni SLuČAJEVI}

Postoje okolnosti kada bi ispovjednik mogao zatražiti savjet od drugoga svećenika kako se postaviti s obzirom na pojedinu vrstu grijeha i kakvu pokoru dati u takvim slučajevima. On to može učiniti, ali bez ulaženja u sve detalje, a još manje eventualne okolnosti koje bi mogle navesti na moguće otkrivanje identiteta pokornika. Nadalje, neki su grijesi toliko teški da ispovjednik mora tražiti od svoga mjerodavnoga poglavara dozvolu za odrješenje. Na primjer, ako netko učiniti svetogrđe s posvećenim česticama ili ih baci, odmah upada u kaznu izopćenja pridržanu Apostolskoj stolici (usp. kan. 1367). Ako se taj grijeh ispovijeda, ispovjednik će se izravno uteći Apostolskoj pokorničarni od koje će tražiti dozvolu za odrješenje toga grijeha i oslobođenje izopćenja. Kada to dobije, pokornik se mora vratiti ispovjedniku kako bi od njega dobio odrješenje i odgovarajuću pokoru. Ili ako svećenik treba vodstvo drugoga, iskusnijega u pitanjima savjesti, prvo mora tražiti dopuštenje od pokorni-

${ }^{26}$ U Ugovoru o pravnim pitanjima između Svete Stolice i Republike Hrvatske sklopljenom 1996., u čl. 8. određuje se: $\gg 1$. U slučaju sudske istrage o kleriku zbog možebitnih krivičnih djela predviđenih krivičnim zakonikom, sudske će vlasti o tome prethodno obavijestiti nadležne crkvene vlasti. 2 . Ispovjedna tajna je u svakom slučaju nepovrediva.« U: HRVATSKA BISKUPSKA KONFERENCIJA, Ugovori izmedu Svete Stolice i Republike Hrvatske, 2001., 31. 
ka za to, nakon čega treba organizirati sljedeći susret s pokornikom. I ovdje svećenik mora identitet pokornika držati u tajnosti.

Ponekad sam pokornik želi razgovarati o sadržaju prethodne ispovijedi, napose o nekom učinjenom grijehu, propustu, okolnostima i to s istim ispovjednikom. Poštujući sakramentalni pečat, svećenik treba zatražiti od pokornika da osvježi njegovo pamćenje.

Naravno, pokornik može govoriti o onome što je rekao u ispovijedi i o primljenim savjetima. Isto tako, može dati dopuštenje bilo ispovjedniku bilo tumaču da objavi sadržaj ispovijedi. I ispovjednik može moliti dopuštenje od pokornika. no to mora biti u izvanrednim situacijama: npr. kako bi se ukrijepila nevaljano sklopljena ženidba.

\section{Povreda sakramentalnoga pečata i tajne ${ }^{27}$}

Na temelju odredbi kann. 983-984 postoje i dva načina povrede sakramentalnoga pečata: izravan i neizravan, koji se kažnjavaju različitim kaznama, a oba su pridržana Kongregaciji za nauk vjere ako je riječ o izvanjskom području ili Apostolskoj pokorničarni ako je riječ o unutarnjem području.

\subsection{Povreda peČAta}

Za izravnu povredu sakramentalnoga pečata traži se objava pokornika i grijeha koji je pokornik učinio. Na primjer, ako ispovjednik kaže: »Marko je ukrao knjigu «, ili: »Marija je pobacila svoje prvo dijete «, ili: »Ani sam danas uskratio odrješenje jer se nije htjela pokajati za nevjeru u braku.« U tim i sličnim slučajevima ispovjednik ipso facto upada u kaznu izopćenja bez potrebe za izvanjskim istupom crkvene vlasti. Riječ je naime o izopćenju latae sententiae pridržanom Apostolskoj stolici. Od toga izopćenja moguće je dobiti oproštenje preko zahtjeva koji će ispovjednik kojemu se svećenik pokornik povjerio u sakramentalnoj ispovijedi, bez imena izopćenoga, poslati na Apostolsku pokorničarnu.

Kod neizravne povrede pečata dovoljna je objava ili imena pokornika ili grijeha koji je pokornik učinio uz postojanje opasnosti saznanja drugoga elementa. Drugim riječima, opasnost postoji onda kada postoji mogućost otkrića identiteta pokornika

\footnotetext{
${ }^{27} \mathrm{O}$ toj temi vidi u: G. INCITTI, Il confessore e il Sacramento della Riconciliazione. Doveri ee diritti dei penitenti dostupno na: http://www.penitenzieria.va/content/dam/penitenzieriaapostolica/ eventi/xxvii-corso-foro-interno/04\%20-\%20Incitti.pdf (11. II. 2017.); G. P. MONTINI, La tutela penale del sacramento della penitenza. I delitti nella celebrazione del sacramento (Cann. 1378; 1387; 1388), u: GRUPPO ITALIANO DOCENTI DI DIRITTO CANONICO (a cura di), Le sanzioni nella Chiesa. XXIII Incontro di Studio Abbazia di Maguzzano - Lonato (Brescia) 1 luglio - 5 luglio 1996., Milano 1997., 213.-235.
} 
ili postoji sumnja da je upravo ta osoba počinila obznanjeni grijeh. Na primjer, ako netko kaže da se Ante ispovjedio kod nekoga svećenika. U tom slučaju kan. 1388 ne predviđa određenu kaznu, nego samo da prekršitelj bude kažnjen $\gg$ prema težini kažnjiva djela «. Ovdje je dakle riječ o kazni ferendae sententiae. Stoga je potreban istup mjerodavne crkvene vlasti (sudac ili ordinarij) na temelju prijave pokornika koji se osjeća $\gg$ izdanim $\ll$ ili $\gg$ oštećenim $\ll{ }^{28}$

Neizravna povreda sakramentalnoga pečata događa se i onda kada onaj koji sluša ne zna da je dotični ispovjednik rečeno saznao u ispovijedi. Na taj slučaj primjenjuje se kan. 1330: »Kažnjivo djelo koje se sastoji u izjavi ili drugom očitovanju volje ili nauka ili znanosti treba da se smatra nedovršenim ako nitko ne opazi tu izjavu ili očitovanje.«

\subsection{Povreda tajne}

Kan. 1388, $\$ 2$ donosi odredbu o obvezi čuvanja ispovjedne tajne. Ta obveza odnosi se na sve one koji nisu »ispovjednik «, a koji na bilo koji način obznanjuju sadržaj ispovijedi drugoga, kao što su tumač ili drugi koji su čuli sadržaj ispovijedi (usp. kan. 983, \$2). Ako navedene osobe povrijede ispovjednu tajnu, one mogu biti kažnjene pravednom kaznom, pa čak i izopćenjem. U tom slučaju riječ je o kazni koja mora biti izrečena, tj. o kazni ferendae sententiae. Isto se može dogoditi i osobi koja lažno optuži ispovjednika da je povrijedio sakramentalni pečat. Stoga je potrebna prijava mjerodavnoj crkvenoj vlast jer u suprotnom ta vlast ni ne može znati o nanesenoj šteti pokorniku pa time i samom sakramentu pokore. U slučaju da se ne intervenira kod crkvene vlasti, onaj koji je povrijedio sakramentalnu tajnu dužan je ispovjediti taj grijeh u sljedećoj ispovijedi.

\subsection{Poseban Slučaj: Snimanje i objavljivanje}

Crkva primjenjuje posebnu pozornost na one koji su povrijedili ispovjednu tajnu audiovizualnim sredstvima društvenoga priopćavanja, a odnosi se na ono što je rekao pokornik ili ispovjednik u sakramentalnoj ispovijedi. U tom slučaju krivac upada u posebnu kaznu izopćenja latae sententiae. Kazna zbog širenja sadržaja ispovijedi spomenutim audiovizualnim sredstvima obvezna je, ali se određuje na temelju okolnosti pod kojima se dogodilo, te se posljedično tomu odlučuje i o eventualnoj kazni gubitka kleričkoga staleža.

Ta kanonska odredba relativno je nova. Prvi istup crkvene vlasti dogodio se 23. ožujka 1973. godine kada se proširila vijest o objavljivanju skandalozne knjige, istinite ili simulirane, snimljene u zloj namjeri. Na temelju posebnih ovlasti koje joj je

${ }^{28}$ Usp. E. MIRAGOLI, Il sigillo sacramentale, u: Quaderni di diritto ecclesiale 3(1990.)3, 418.-419. 
dao vrhovni crkveni autoritet Kongregacija za nauk vjere u svom dekretu određuje da svatko tko uz uporabu bilo kojega tehničkoga sredstva uhvati ili širi sredstvima društvenoga priopćivanja ono što je rekao ispovjednik ili pokornik u sakramentalnoj ispovijedi, stvarnoj ili izmišljenoj, koju je učinio isti subjekt ili drugi, upada u kaznu izopćenja latae sententiae. ${ }^{29}$

Tom izjavom proglašena je dakle kazna izopćenja latae sententiae autorima i izdavačima spomenute knjige te svima onima koji bi aktivno sudjelovali u njezinu nastanku i objavljivanju. ${ }^{30}$ Ista Kongregacija izdala je u rujnu 1988. godine dekret kojim se ta odredba primjenjuje na sve buduće analogne slučajeve. Kako bi zaštitila svetost ispovijedi, odnosno obranila pravo posvećenih službenika i vjernika na ispovijed, pozvavši se na kan. 1388, Kongregacija određuje kaznu izopćenja latae sententiae za svakoga tko bilo kojim tehničkim sredstvom snimi ili širi rečeno u ispovijedi. Svrha dekreta jest $\gg$ štiti svetost sakramenta pokore i [...] braniti prava posvećenih službenika i kršćanskih vjernika «. ${ }^{31}$

Osim tih dvaju dokumenata, moramo spomenuti još dva iste Kongregacije nedavno objavljena, a odnose se na našu problematiku. Prvi dokument jest apostolsko pismo Sacramentorum sanctitatis tutela (u daljnjem tekstu SST) Ivana Pavla II. od 30. travnja 2001. godine kojim se proglašavaju odredbe o teškim kažnjivim djelima pridržanim Kongregaciji za nauk vjere (Normae de gravioribus delictis) kako bi se sačuvala svetost sakramenata euharistije i ispovijedi te ćudoređa. $S$ obzirom na sakrament pokore pismo navodi da su sljedeća kaznena djela pridržana istoj Kongregaciji: odrješenje sukrivca u grijehu protiv šeste Božje zapovijedi, ispovjednikovo navođenje pokornika na grijeh protiv šeste Božje zapovijedi za vrijeme ili pod izlikom ispovijedi te izravna povreda sakramentalnoga pečata. ${ }^{32}$

Drugi dokument Kongregacije jest pismo, upućeno 21. svibnja 2010. godine svim biskupima Katoličke Crkve i drugim ordinarijima i poglavarima, u kojem se tumače uvedene promjene u spomenutom apostolskom pismu Sacramentorum sanctitatis tutela. U čl. $4 \$ 2$ Kongregacija određuje da tko god bude tehničkim sredstvima širio

\footnotetext{
${ }^{29}$ Usp. E. MIRAGOLI, Il sigillo sacramentale, 420.

${ }^{30}$ Usp. CONGREGATIO PRO DOCTRINA FIDEI, Declaratio de tuenda Sacramenti Paenitentiae dignitate, u: AAS 65 (1973.), 678.

${ }^{31}$ CONGREGATIO PRO DOCTRINA FIDEI, Decreto riguardante la scomunica a colui che divulga la confessioni, u: AAS 80 (1988.), 1367.

${ }^{32}$ Usp. CONGREGATIO PRO DOCTRINA FIDEI, Motu proprio Sacramentorum sanctitatis tutela riguardante le norme sui delitti piu gravi riservati alla Congregazione per la Dottrina della Fede, u: AAS 93 (2001.), 737.-739.
} 
sadržaj ispovijedi, bit će kažnjen prema težini kaznenoga djela. Ako je riječ o kleri$\mathrm{ku}$, predviđa se i gubitak kleričkoga staleža. ${ }^{33}$

\subsection{KORIŠTENJE ZNANJEM NA ŠTETU POKORNIKA}

Kan 984 određuje sljedeće: $\$ 1$. »Ispovjedniku se posve zabranjuje služiti se na štetu pokornika znanjem do kojeg je došao u ispovijedi, pa i kad je isključena svaka pogibelj otkrivanja. \$2. Tko zadobije vlast, ne može se ni na koji način u izvanjskom upravljanju služiti znanjem o grijesima što ga je u bilo koje vrijeme stekao ispovijedajući.«

Ta kanonska odredba jamči da ono što je rečeno u sakramentalnoj ispovijedi ili in foro Dei i ostane na tom području. Naime, pokornik koji s vjerom ide na ispovijed u namjeri da ponovno uđe u stanje milosti mora biti siguran da ne će doživjeti nikakvu štetu ili zle posljedice nakon ispovijedi. U isto vrijeme kanonska odredba štiti i ostale vjernike. Kada bi ispovjedniku bilo dopušteno koristiti se saznanjima iz ispovijedi na štetu drugih, nastao bi glas koji, općenito, mnogi vjernici imaju o tom sakramentu, a vodi prema tomu da bi on bio instrument kontrole i vladanja nad drugima. Ispovjednik koji ne bi poštovao tu odredbu sagriješio bi ne samo protiv pravednosti nego bi učinio i sakrilegij s obzirom na sakrament pokore. Ono što ispovjednik sazna za vrijeme sakramentalnoga čina posljedica je povjerenja koje pokornik u njega stavlja kao Božjega službenika. Objavljivanjem drugima činio bi izdaju pokornika i zakonitu povredu njegova dobroga glasa. Povreda pečata (pa čak i sama mogućnost da se to dogodi) učinila bi omraženim spomenuti sakrament i samoga ispovjednika koji djeluje in persona Christi.

\section{Posljedice povrede sakramentalnoga pečata $\mathrm{i}$ ispovjedne tajne}

Ako se povreda sakramentalnoga pečata dogodi pod točno određenim uvjetima, tada možemo govoriti o kaznenom djelu povrede sakramentalnoga pečata. $\mathrm{O}$ tome nam govori kan. 1388, $\$ 1$ : $\gg$ Ispovjednik koji izravno povrijedi sakramentalni pečat upada u izopćenje unaprijed izrečeno, pridržano Apostolskoj Stolici; onaj pak koji to učini samo neizravno neka se kazni prema težini kažnjivog djela.« Kod izravne povrede pečata kazna se ipso facto primjenjuje. Neizravna povreda pečata predviđa određenu stupnjevitost kažnjavanja, odnosno kazna je proporcionalna težini neizravne povrede pečata.

${ }^{33}$ Usp. CONGREGATIO PRO DOCTRINA FIDEI, Normae de delictis Congregationi pro Doctrina Fidei reservatis seu Normae de delictis contra fidem necnon de gravioribus delictis, u: AAS 102 (2010.), 419.-434. 
S obzirom na povredu ispovjedne tajne isti kanon u $\$ 2$ određuje: »Tumač i drugi, o kojima se govori u kan. 983, $\$ 2$, koji povrijede tajnu neka se kazne pravednom kaznom, ne isključivši izopćenje.«

Dakle, Zakonik propisuje kažnjivo djelo i kaznu u slučaju povrede pečata ili tajne. Kako bismo bolje razumjeli kanonsko značenje kažnjivoga djela i kazne, treba ih definirati. Prema kan. 2195, $\$ 1$ Kodeksa iz 1917. godine pod nazivom se kažnjivoga (kaznenoga) djela u crkvenom pravu podrazumijeva »izvanjska i ćudoredno ubrojiva povreda zakona, uz koji je dodana kanonska kaznena prinuda barem neodređena $\ll .34$

Definiciju crkvene kazne također nalazimo u Kodeksu iz 1917. godine i to u kan. 2215 prema kojemu je ona »oduzeće nekoga dobra kojim nadležna vlast udara počinitelja krivičnog djela, da ga popravi i da djelo bude kažnjeno ${ }^{35}{ }^{5} \mathrm{Zbog}$ ozbiljnosti kazne jasno je koliko je svet sakramentalni pečat u očima Crkve.

Već smo govorili o razlici između izravne i neizravne povrede sakramentalnoga pečata. O toj razlici ovisit će i kazna koja slijedi nakon počinjenoga djela.

\section{Kanonsko-kazneni postupak}

U Katoličkoj Crkvi postoji jedan poseban postupak kojim se rješavaju najteža kaznena djela koja su počinili njezini kršteni članovi. Prije 1983. godine bile su donesene različite odredbe o tome koje su proglašenjem aktualnoga ZKP-a prestale važiti. Međutim, pojavila se određena lacuna legis koja je ispravljena 2001. godine motuproprijem Sacramentorum sanctitatis tutela kojim se proglašavaju Normae de gravioribus delictis, odnosno odredbe kojima se reguliraju najteža kaznena djela.

Nakon toga dokumenta i u svjetlu iskustva rada Svete stolice uvidjelo se da je potrebna reforma važećega zakonodavstva. Rezultat su te reforme promjene spomenutih odredbi de gravioribus delictis koje je 15. lipnja 2010. godine donijela Kongregacija za nauk vjere odobrenjem rimskoga prvosvećenika Benedikta XVI.

Teška kažnjiva djela odnose se na tri elementa: teška povreda sakramenta euharistije, sakramenta pokore i kažnjivo djelo protiv ćudoređa. Nas zanima sakrament pokore ili pomirenja.

Da bi se moglo govoriti o kažnjivom djelu protiv spomenutoga sakramenta, ono se može dogoditi na sljedeće načine: 1 . odrješenje sukrivca protiv šeste zapovijedi

\footnotetext{
${ }^{34}$ Can. 2195, \ 1: »Nomine delicti, iure ecclesiastico, intelligitur externa et moraliter imputabilis legis violatio cui addita sit sanctio canonica saltem indeterminata.«

${ }^{35}$ Can. 2215: »privatio alicuius boni ad delinquentis correctionem et delicti punitionem a legitima auctoritate inflicta.«
} 
- kazna: izopćenje latae sententiae pridržano Apostolskoj stolici; 2. pokušaj sakramentalnoga odrješenja - kazna: izopćenje latae sententiae ili suspenzija; 3. simulacija sakramentalnoga odrješenja -kazna: pravedna; 4. ispovjednikovo nagovaranje pokornika na grijeh protiv šeste zapovijedi - kazna: suspenzija, zabrana ili oduzeće, a u težim slučajevima gubitak kleričkoga staleža; 5. izravna ili neizravna povreda sakramentalnoga pečata - kazna: izopćenje latae sententiae pridržano Apostolskoj stolici (izravna povreda) ili kazna proporcionalna težini djela (neizravna povreda); 6. širenje na bilo koji način bilo kojim sredstvima sadržaja ispovijedi - kazna: izopćenje latae sententiae, pa čak i gubitak kleričkoga staleža.

Prema apostolskoj konstituciji Pastor bonus 52 (u daljnjem tekstu PB), Kongregacija za nauk vjere mjerodavna je samo u slučajevima kažnjivoga djela počinjenoga na izvanjskom području. Apostolska pokorničarna mjerodavna je za unutarnje područje, bilo sakramentalno bilo nesakramentalno, te daje odrješenja, oproste, sankcije, kazne i ostale milosti. ${ }^{36}$

Kao što vidimo, kod izravne povrede sakramentalnoga pečata izopćenje (excommunicatio) je najteža kazna, dok kod neizravne povrede, bilo pečata bilo tajne, kazne mogu biti različite ovisno o težini kažnjiva djela. U javnosti se često govori o izopćenju, a da pri tome mnogima nije jasno što je to i na koga se odnosi. Radi jasnoće samoga pojma i njegove primjene potrebno je osvrnuti se na Kodeks iz 1917. godine koji u kan. 2257, \$1 donosi definiciju izopćenja: »izopćenje je kaznena zabrana, kojom se neka osoba isključuje iz zajedništva s vjernicima uz učinke, koji su iscrpno naznačeni u kanonima, koji slijede i koje se ne mogu odvajati.«

Prema aktualnom zakonodavstvu Katoličke Crkve ispovjednik koji izravno povrijedi sakramentalni pečat upada u kaznu izopćenja latae sententiae pridržane isključivo Kongregaciji za nauk vjere. ${ }^{37}$ Osim izopćenja, postoje još dvije kazne, a to su zabrana bogoslužja (interdictum) i kazna obustave (suspensio). Definicije zabrane bogoslužja i obustave također nalazimo u Kodeksu iz 1917. godine. Prema kan. 2268, $\$ 1$ uskrata (zabrana) bogoslužja »kaznena je zabrana, kojom se vjernicima, koji inače ostaju u crkvenom zajedništvu, brane bogoslužni čini «. Obustava je, prema kan. 2278 , \$1, »kaznena zabrana, kojom se duhovniku obustavlja služba ili nadarbina ili jedno i drugo «. Zabrana bogoslužja može se primijeniti i na vjernika laika i na vjernika klerika. Međutim, kazna obustave odnosi se samo na vjernika klerika.

\footnotetext{
${ }^{36}$ Usp. IOANNES PAULUS II., Constitutio apostolica de Romana curia Pastor bonus; hrvatski prijevod: IVAN PAVAO II., Apostolska konstitucija o Rimskoj kuriji Dobri pastir, u: Zakonik kanonskoga prava. Proglašen vlašću Ivana Pavla II., s izvorima, Zagreb, 1996.

${ }^{37}$ Usp. SST, čl. 3, $3^{\circ}$.
} 
U svim trima navedenim slučajevima riječ je, zapravo, o popravnim kaznama ili cenzurama ${ }^{38}$ koje dovode do $\gg$ uskraćivanja određenih duhovnih is duhovnim povezanih dobara, kao što su, npr. služenje ili primanje sakramenata ili blagoslovina, obavljanje crkvene službe ili služenja, vršenje čina upravljanja, crkvene povlastice, plodovi dostojanstva, službe i zadaće i sl. $\ll^{39}$.

Budući da je riječ o cenzurama, one ne prestaju same od sebe, nego samo otpuštanjem koje daje mjerodavna crkvena vlast. Da bi uopće moglo doći do otpuštanja, gleda se ponašanje krivca, odnosno onoga koji je počinio neko od navedenih kažnjivih djela. Ako krivac ne odustane od svoje tvrdokornosti, otpuštanje cenzure mu se ne može dati. Ako krivac ozbiljno odustane od svoje tvrdokornosti, tada mu se otpuštanje ne može uskratiti (kan. 1358, \$1).

Prema tomu, cenzure nemaju naznaku trajanja, ne mogu se nametnuti $\gg$ na određeno vrijeme $\ll($ ad tempus praefinitum $)$ ni $\gg$ do naše volje $\ll$ (ad beneplacitum nostrum), a još manje trajno (in perpetuum).$^{40}$

Mjerodavna crkvena vlast za otpuštanje cenzura jesu ordinarij, ordinarij mjesta te u posebnim okolnostima za to određeni prezbiteri. Mi ćemo se napose zaustaviti na ulozi Apostolske pokorničarne te njezinoj mjerodavnosti na unutarnjem sakramentalnom području pri otpuštanju navedenih cenzura.

\section{Apostolska pokorničarna}

Apostolska pokorničarna najstariji je dikasterij Rimske kurije čiji nastanak počinje već u 12. stoljeću. To je ujedno i prvi od apostolskih sudova čija je mjerodavnost isključivo unutarnje područje, tj. intimno područje odnosa između Boga i grješnika. Ostala dva suda, Apostolska signatura i Rimska rota, obavljaju svoje djelovanje na tipično sudskom području, tj. svega onoga što se tiče izvanjskoga područja. Apostolska pokorničarna kao dikasterij za unutarnje područje nije sud u modernom smislu, kao što su to spomenuta Apostolska signatura i Rimska rota. Ona to nije zato što njezino djelovanje nije parničnoga karaktera, nego voljnoga; ne događa se na javan način, nego upravo na tajan, tj. unutarnji.

Svrha i služba Pokorničarne jest spas duša (salus animarum, usp. kan. 1752). Zapravo su sva tijela Rimske kurije usmjerena prema spasu duša, no Pokorničarna to čini

\footnotetext{
${ }^{38}$ Definiciju cenzure ili poravne kazne nalazimo u Kodeksu iz 1917. u kan. 2241, \ 1: $\gg$ Kaznena je zabrana (censura) takova kazna, kojom se čovjeku krštenomu, koji je počinio krivično djelo i koji je uporan, oduzimlju neka dobra duhovna ili s duhovnim spojena, dok ne bude, pošto prestane biti upornim, odriješen.«

${ }^{39}$ N. ŠKALABRIN, Kaznene mjere u Crkvi, Đakovo, 2004., 73.

${ }^{40}$ Usp. isto, 74.
} 
izravno, neposredno. Bitna svrha rada Pokorničarne jest omogućiti i olakšati vjerniku hod na putu pomirenja s Bogom i Crkvom. Apostolska pokorničarna naziva se i Sud milosrđa jer je njezino djelovanje isključivo povezano s unutarnjim područjem. Ono se ne odnosi samo na grijehe, cenzure ili nepravilnosti nego i na oproste te na sve moralne i pravne dvojbe povezane s unutarnjim područjem.

Apostolska konstitucija o Rimskoj kuriji Pastores dabo vobis u čl. 117 - 120 donosi odredbe o Apostolskoj pokorničarni. U njezinu mjerodavnost pripada sve ono što se tiče unutarnjega područja i oprostâ (čl. 117). Za unutarnje, bilo sakramentalno bilo nesakramentalno, područje podjeljuje odrješenja, oproste, zamjene ozdravljenja, oproštenja i druge milosti (čl. 118). Osim toga, njezina je briga da bude dovoljan broj pokorničara u rimskim patrijarhijskim bazilikama (čl. 119). Njoj se povjerava davanje oprosta, a sve upite koji se tiču dogmatskoga karaktera prepušta Kongregaciji za nauk vjere (čl. 120).

\subsection{NAČINI POSTUPANJA ISPOVJEDNIKA ${ }^{41}$}

Ako pokornik koji je upao u cenzuru pridržanu Apostolskoj stolici dođe na ispovijed, tada ispovjednik može djelovati na dva načina:

a) Ispovjednik treba objasniti pokorniku njegov kanonski status poučivši ga o obvezi ulaganja utoka kako bi dobio otpuštanje cenzure. Mogao bi i sâm pokornik to učiniti, no bolje je da to učini ispovjednik. Zatim ispovjednik treba dogovoriti novi susret s pokornikom. U utoku, koji će podnijeti, mora jasno izložiti ono što se dogodilo, zatražiti dopuštenje da smije odriješiti pokornika od cenzure u koju je upao te smjernice o pokori koju namjerava nametnuti pokorniku. Nakon dobivenoga odgovora Apostolske pokorničarne pokornik se vraća ispovjedniku kako bi mu otpustio cenzuru i odriješio ga od grijeha te mu dao prikladnu pokoru.

b) Druga mogućnost jest »odrješenje hitnog slučaja «. Pod pojmom hitan slučaj podrazumijeva se bol i teškoća koji bi se uzrokovali pokorniku da nekoliko tjedana bude bez odrješenja grijeha i bez mogućnosti primanja pričesti. Ako je pokorniku, koji se realno pokajao zbog učinjenoga kažnjiva djela, uistinu teško duže ostati u stanju teškoga grijeha bez primanja sakramenata, tada ga ispovjednik na temelju kan. 1357 može odriješiti od cenzura i grijeha zatraživši da mu se vrati nakon nekoliko tjedana $u$ dan i sat kada im odgovara kako bi mu

${ }^{41}$ Taj dio obrađen je prema izlaganju dr. Krzysztofa Nykiela, upravitelja Apostolske pokorničarne, pri otvorenju tečaja o unutarnjem području 2016. Usp. K. NYKIEL, La Penitenzieria Apostolica: struttura, competenza, prassi, u: Penitenzieria Apostolica, XXVII Corso sul foro interno, Roma 2016., 7.-8.; 10.-11. Dostupno na: http://www.penitenzieria.va/content/dam/penitenzieriaapostolica/eventi/xxvii-corso-foro-interno/02\%20-\%20Nykiel.pdf. (11. II. 2017.). 
nametnuo pokoru. Ispovjednik treba djelovati u roku od 30 dana i izvijestiti Apostolsku pokorničarnu o učinjenom i o pokori. Pokorničarna će proučiti slučaj, potvrdit će otpuštanje te dati smjernice za nametanje pokore.

Nakon što se pokornik vrati istom ispovjedniku u dogovoreni dan i sat, ispovjednik će najprije upotrijebiti sljedeću formulu za otpuštanje cenzure: »Snagom vlasti koja mi je dana ja te odrješujem od spone izopćenja (ili zabrane ili suspenzije) u ime Oca i Sina i Duha Svetoga. $\ll^{42}$

Nakon toga će ga odriješiti od grijeha prema sljedećoj formuli: »Bog, Otac milosrđa, koji je smrću i uskrsnućem svojega Sina pomirio sa sobom svijet i izlio Duha Svetoga za otpuštenje grijeha, neka ti po službi Crkve udijeli oproštenje i mir. I ja te odrješujem od grijeha tvojih u ime Oca i Sina i Duha Svetoga. ${ }^{43}$

\subsection{POKORNIK LAIK ILI KLERIK}

Ako je riječ o pokorniku laiku, utok na Apostolsku pokorničarnu uputit će njegov ispovjednik. Utok se sastoji od uobičajenoga jednostavnoga pisma u kojem ispovjednik, ispustivši ime pokornika i bilo koji element koji bi mogao dovesti do otkrića njegova identiteta, moli Pokorničarnu dopuštenje da odriješi od cenzure ili ju informira da je već odriješio koristeći se dopuštenjem na temelju kan 1357. Naravno da utok uvijek mora biti učinjen u pismenom obliku. Kao sredstva komuniciranja nisu dopušteni telefon, faks ili elektronička pošta jer se smatra da pismo bolje jamči nepovredivost sakramenta s obzirom na to da je riječ o materiji zaštićenoj ispovjednom tajnom.

U slučaju kažnjiva djela klerikove izravne povrede sakramentalnoga pečata potrebno je dostaviti: približnu dob pokornika; kada je učinjeno kažnjivo djelo; zašto; koliko puta; pod kojim okolnostima; je li riječ o svećeniku koji je žrtva vlastite skrupuloznosti; je li to namjerno učinio ili zbog nepažnje; je li pokornik ispovjednik koji je u toj materiji uobičajeno oprezan; jesu li nazočni primijetili da to što je rekao proizlazi iz sakramenta ispovijedi; je li nastala šteta za pokornika i kakva.

\subsection{IME, JEZIK I ODGOVOR}

Budući da je riječ o unutarnjem području, ispovjednik mora poduzeti sve moguće mjere kako bi sakramentalni pečat ostao zaštićen. Stoga nikada ne smije napisati

\footnotetext{
${ }^{42}$ Vlastiti prijevod formule za otpuštanje cenzure. Izvorni tekst nalazi se na mrežnoj stranici Apostolske pokorničarne koja donosi i ostale upute i tehničke detalje kojih se svi ispovjednici moraju držati. Dostupno na: http://www.penitenzieria.va/content/dam/penitenzieriaapostolica/Promemoria\%20per\%20il\%20confessore\%20-\%20ITA.pdf (11. II. 2017.).

${ }^{43}$ RIMSKI OBREDNIK, Red pokore, Zagreb, 2009. Riječ je o prepravljenoj molitvi odrješenja o čemu više u: D. VUKOVIĆ, Odrješenje i pomirenje kao darovi Božje milosrdne ljubavi, u: Diacovensia $24(2016)$.4 , 555.-566.
} 
ime pokornika ni navesti nešto što bi moglo dovesti do mogućega otkrića njegova identiteta. Na primjer, ne smije navesti imena mjesta prebivališta ni veličinu tih mjesta; ne smije navesti ni pojedinosti župe ili institucije kojoj pokornik pripada. Isto tako, ne smije navesti ni je li riječ o sjemeništu ili nekoj ustanovi posvećenoga života.

Ako se dogodi da je navedeno ime pokornika, Pokorničarna ga uvijek briše iz svih spisa. Štoviše, sve ono što se tiče određenoga postupka, a u vezi je sa savješću, nakon 20 godina potpuno se uništava. $U$ arhivu Pokorničarne čuvaju se samo oni dokumenti koji zbog svoje težine, složenosti ili posebnosti zahtijevaju određeno produbljenje na moralno-pravnom području, a koje su navedene u tzv. votum ili mišljenju.

Kada je riječ o jeziku, prije se inzistiralo na latinskom. Danas su u uporabi moderni jezici kao što su španjolski, engleski, francuski, portugalski, talijanski, njemački i poljski. Ako se koristi manje poznatim jezikom, Pokorničarna traži pomoć od ispovjednika četiriju papinskih bazilika grada Rima. Odgovor Pokorničarne piše se na jeziku na kojem je i pokrenut postupak ili na jeziku koji zatraži sam ispovjednik. Međutim, latinski jezik i dalje je u uporabi te se njime može koristiti.

\subsection{Struktura Pisma}

Pri predstavljanju slučaja ispovjednik mora biti sažet, ali u isto vrijeme mora označiti bitne elemente slučaja te ostale korisne podatke za Pokorničarnu kako bi se formirao objektivan sud za davanje prikladnoga rješenja. Zbog činjenice da su slučajevi savjesti podložni raznim i nepredvidivim elementima ostavljeno je razboritom sudu ispovjednika da razlikuje bitne elemente slučaja, one važnije ili, jednostavno, one korisne od beznačajnih i nekorisnih koje treba ispustiti. Kao što je kod sakramenta pokore potrebno specificirati tko, kako, kada, kojim sredstvima itd., tako je potrebno predstaviti okolnosti koje mijenjaju vrste, otežavajuće ili olakotne, koje idu ili ne idu u prilog pokorniku. Sud ispovjednika o psihoafektivnom stanju samoga pokornika prijeko je potreban (izrečen coram Deo). Također treba naznačiti je li pokornik već bio odriješen na temelju kan. 1357.

\subsection{IZNIMKE}

Ako je riječ o cenzurama kojima su udareni posvećeni službenici, treba imati na umu kan. 1335 na temelju kojega je moguće obavljati službu unatoč cenzuri kada je to potrebno zbog duhovnih potreba vjernika koji bi se mogao naći u smrtnoj opasnosti. Ako cenzura latae sententiae nije proglašena, svaki put kada vjernik zatraži neki sakrament, blagoslovinu ili čin upravljanja citirani kanon nadodaje da je »takav zahtjev dozvoljen zbog bilo kojeg opravdanog razloga «. 


\title{
9. Ogledni obrazac utoka na Apostolsku pokorničarnu
}

U slučaju izravne povrede sakramentalnoga pečata kao primjer kako bi sadržajno mogao izgledati utok donosimo izmišljen slučaj:

Adresa

Mjesto i nadnevak

\author{
Njegova Uzoritost \\ Kard. Mauro Piacenza \\ Sud Apostolske pokorničarne \\ 00120 CITTÀ DEL VATICANO
}

Uzor. kardinale Piacenza,

Prije nekoliko dana došao mi je na ispovijed vlč. XY, svećenik u 30-im godinama, koji mi je pri tom priznao da je prije dva tjedna izravno povrijedio sakramentalni pečat. Naime, pri jednoj večeri s kolegama svećenicima vlč. XY rekao je da ni u kojem slučaju vlč. NN ne bi smio biti izabran za župnika jer ima psihičkih poteškoća s kontroliranjem svoje žestoke naravi. To što je vlč. XY rekao od vlč. NN saznao je $\mathrm{u}$ ispovijedi.

Nakon što sam ga saslušao, rekao sam mu da je izravno povrijedio sakramentalni pečat jer je rekao ispovjeđeni grijeh i identitet pokornika.

Spomenuti vlč. XY zbog toga se iskreno pokajao. On smatra da nije nastala velika šteta za vlč. $\mathrm{NN}$ jer mnogi znaju za te njegove probleme.

Uzevši u obzir njegovo iskreno kajanje i žaljenje zbog učinjenoga, smatrao sam mogućim i opravdanim da mu na temelju kan. 1357 podijelim otpuštenje cenzure te ga odriješim od svih njegovih ispovjeđenih grijeha. Kao pokoru dao sam mu da ode u samostan NN na sedam dana gdje će obaviti duhovne vježbe. Vlč. XY ponovno će mi doći na ispovijed za četiri tjedna u nadi da ćete mi Vi do tada u Vašem odgovoru dati još konkretnije smjernice za dodatnu pokoru koju ću mu tada nametnuti.

Odan u Kristu

Vlč...

potpis 


\section{Zaključak}

Sakramentalni pečat odnosi se na svećenika ispovjednika (kan. 983, $\$ 1$ ), dok se ispovjedna tajna odnosi na bilo koju drugu osobu koja je iz bilo kojega razloga umiješana u slavlje sakramenta pokore (kan. 983, \$2). Zabrana objavljivanja sadržaja ispovijedi izrečena riječima: »ne smije $\ll$, apsolutna je, a svaka njezina povreda određena je kao ispovjednikova »izdaja « pokornika. Ta obveza čuvanja sakramentalnoga pečata proizlazi iz božanskoga zakona, a crkveno je pozitivno pravo štiti i jamčiti njezinu sakralnost.

S obzirom na materiju sakramentalnoga pečata izravna su materija svi smrtni i teški grijesi te laki, pojedinačno ispovjeđeni. Isto tako i uskraćeno odrješenje, teška pokora, okolnosti vremena, mjesta i načina povezani s grijesima i pokornikom ili eventualnim sukrivcem te grijesi drugih osoba koje je pokornik eventualno spomenuo u ispovijedi.

Neizravna materija jesu fizički i psihički nedostatci pokornika, njegovo materijalno stanje, osobna mišljenja, način ponašanja na ispovijedi.

Ispovjedna tajna (kan. 983, $\$ 2$ ) odnosi se na tumača i bilo koju drugu osobu koja bi došla do saznanja sadržaja ispovijedi. Ta obveza tajne proizlazi iz naravnoga prava (kao i sakramentalni pečat) te iz pozitivnoga prava Crkve.

Naposljetku, kan. 984 zabranjuje ispovjedniku uporabu stečenoga znanja iz ispovijedi na izvanjskom području i ta je zabrana apsolutna na temelju $\$ 1$. U $\$ 2$ zakonodavac predviđa jedan poseban slučaj koji je dosta čest u pastoralnom životu dušobrižnika. Kršenje obveze ne smatra se neizravnom povredom sakramentalnoga pečata, nego povredom ispovjedne tajne.

Ako se dogodi povreda sakramentalnoga pečata, počinje djelovati postupak primjene kazne: prethodna istraga, sudska faza pridržana Svetoj stolici koja se odvija ili sudskim kaznenim putem ili upravnim. Na kraju se izriče i primjenjuje sama kazna. Nakon što je kazna obavljena, slijedi otpuštanje kazne, osim ako je riječ o recidivu.

Složenost kanonskih odredaba o sakramentalnom pečatu i ispovjednoj tajni pokazuje jasan stav Crkve kojim štiti odnos pokornika i njegove intime s Bogom u sakramentalnoj ispovijedi. 


\title{
THE SACRAMENTAL SEAL AND THE SECRET OF CONFESSION
}

\author{
Zdenko ILIĆ*
}

Summary: When a person unburdens their soul to a priest to confess their sins in the sacrament of penance, a sacred bond is formed between them. It is Christ who forgives sins through the priest as the minister of the sacrament of penance. The priest cannot disclose what was said in confession to anyone and is bound by absolute professional secrecy which is called the sacramental seal. The canons 983-984 deal with two aspects of secrecy which the confessor and others who may acquire knowledge from the celebration of the sacrament of penance must observe. The secrecy pertains to everything heard in the individual confession. According to the Can. 983, the sacramental seal is inviolable. The confessor cannot reveal the contents of a confession either directly or indirectly, by some sign, suggestion, or action. If a confessor directly violates the sacramental seal, he incurs an automatic (latae sententiae) excommunication reserved to the Apostolic See. If he does so indirectly, he is to be punished (ferendae sententiae) according to the seriousness of the offense (Can. 1388, S1). Besides the confessor, an interpreter and anyone else who in any way have knowledge of sins from confession are also obliged to observe secrecy. If they do not adhere to that, they are to be punished with a just penalty, not excluding excommunication (Can. 1388, \$2).

In the case of direct violation of the sacramental seal, the Apostolic Penitentiary has competence for the remission of the penalty of excommunication by a special proceeding. In other cases, the competence lies with the Ordinary.

Keywords: sacrament of penance, sacramental seal, secret of confession, confessor, penitent, direct and indirect violation, excommunication, Apostolic Penitentiary.

\footnotetext{
* Zdenko Ilić, Ph. D., Catholic Faculty of Theology in Đakovo, J. J. Strossmayer University of Osijek, P. Preradovića 17, 31400 Đakovo, Croatia, zdenko.ilic@os.t-com.hr
} 